\title{
Inhibition of human rheumatoid arthritis synovial cell survival by hecogenin and tigogenin is associated with increased apoptosis, 38 mitogen-activated protein kinase activity and upregulation of cyclooxygenase-2
}

\author{
BERTRAND LIAGRE ${ }^{1}$, PASCALE VERGNE-SALLE $^{2},{\text { DAVID Y. } \text { LEGER }^{1} \text { and JEAN-LOUIS BENEYTOUT }}^{1}$ \\ ${ }^{1}$ Laboratoire de Biochimie, UPRES EA 4021, Faculté de Pharmacie, 2 rue du Docteur Marcland, 87025 Limoges Cedex; \\ ${ }^{2}$ Service de Rhumatologie et Thérapeutique, CHRU Dupuytren, 2 avenue Martin Luther King, 87042 Limoges Cedex, France
}

Received May 10, 2007; Accepted June 25, 2007

\begin{abstract}
We conducted our study to assess the antiproliferative and proapoptotic potential of hecogenin and tigogenin, two saponins which are structurally similar to diosgenin. We particularly focused our attention on mitogenactivated protein kinase (MAPK) activation in relation to apoptosis but also with the COX-2 expression and activity. Rheumatoid arthritis (RA) synoviocytes were isolated from fresh synovial biopsies obtained from five RA patients undergoing hip arthroplasty. Measurement of cell proliferation was determined using the MTT assay. Apoptosis was evaluated by studying caspase- 8 , caspase- 9 and caspase- 3 activities but also by quantification of DNA fragmentation. Quantification of human phospho-MAPKs was realized by ELISA. COX-2 expression was demonstrated by Western blot analysis and COX-2 activity by assay of endogenous prostaglandin $\mathrm{E}_{2}\left(\mathrm{PGE}_{2}\right)$ production. Tigogenin was more effective than hecogenin in inducing apoptosis in human RA fibroblast-like synoviocytes (FLS) which was caspase dependent but poly(ADP-ribose) polymerase independent
\end{abstract}

Correspondence to: Dr Bertrand Liagre, Laboratoire de Biochimie, UPRES EA 4021, Faculté de Pharmacie, 2 rue du Docteur Marcland, 87025 Limoges Cedex, France

E-mail: bertrand.liagre@unilim.fr

Abbreviations: COX, cyclooxygenase; DMEM, Dulbecco's modified Eagle's medium; ELISA, enzyme-linked immunosorbent assay; ERK, extracellular signal-related kinase; FCS, fetal calf serum; FLS, fibroblast-like synoviocytes; IL, interleukin; JNK, cJun N-terminal kinase; MAPK, mitogen-activated protein kinase; MTT, 3-(4,5-dimethylthiazol-2-yl)-2,5-diphenyltetrazolium bromide; OD, optical density; PARP, poly(ADP-ribose) polymerase; PLSD, Fisher's Protected Least Significant Difference; $\mathrm{PG}$, prostaglandin; RA, rheumatoid arthritis

Key words: human synoviocytes, apoptosis, saponin, cyclooxygenase-2,p38 MAPK and characterized by DNA fragmentation. Our results demonstrated hecogenin- and tigogenin-induced apoptosis through activation of p38 without affecting the JNK and ERK pathways. Indeed, pretreatment with a p38 inhibitor decreased saponin-induced apoptosis with a significant decrease in DNA fragmentation. Furthermore, the rate of apoptosis induced by hecogenin or tigogenin was associated with overexpression of COX-2 correlated with overproduction of endogenous $\mathrm{PGE}_{2}$. These new results provide strong evidence that a family of structurally similar plant steroids is capable of inducing apoptosis in human RA FLS with different rates and different signalling pathways. This study also confirms the discussed appearance of the downregulation or upregulation of COX-2 in cell apoptosis as a function of cell type.

\section{Introduction}

Plant steroids have been thoroughly described for their pharmacological properties, including hypocholesterolemic $(1)$, antidiabetic (2) and antioxidant activities $(3,4)$. Particular attention has been given to their potential for cancer chemoprevention, especially as apoptosis inducers (5-10).

Apoptosis is considered to be one of the mechanisms regulating autoimmune diseases such as rheumatoid arthritis (RA) (11). In the pathogenesis of RA, it is thought that the normal balance between proliferation and apoptosis of synovial fibroblasts is lost, leading to hyperplasia of these fibroblasts (12). Activated synovial cells cause growth of synovium in the articular cavity along with angiogenesis, invade the adjacent bone, promote production of inflammatory mediators by inflammatory cells, and cause cartilage and bone destruction (13). Therefore, it has been shown that stimulation of apoptosis in synovial fibroblasts might be useful for the treatment of RA $(14,15)$.

We showed for the first time that a plant steroid, diosgenin, inhibited the growth of human RA fibroblast-like synoviocytes (FLS) with apoptosis induction characterized by a loss of mitochondrial membrane potential, caspase- 3 activation and DNA fragmentation (16). Furthermore, the proapoptotic effect of diosgenin was associated with over- 
expression of cyclooxygenase-2 (COX-2) correlated with the overproduction of endogenous prostaglandin $\mathrm{E}_{2}\left(\mathrm{PGE}_{2}\right)(16)$.

Furthermore, we described that diosgenin was the most effective as a cell death inducer compared to two other plant steroids (hecogenin and tigogenin) in the human osteosarcoma 1547 cell line (17). Another study with a series of five saponins structurally similar to diosgenin described the structure-function relationship for saponin effects on cell cycle arrest and apoptosis in osteosarcoma cells using a molecular modelling approach (18).

In this context, we conducted our study to assess the antiproliferative and proapoptotic potential of hecogenin and tigogenin, two saponins which are structurally similar to diosgenin. We particularly focused our attention on mitogenactivated protein kinase (MAPK) activation in relation to apoptosis but also with the COX-2 expression and activity. Our results demonstrate that hecogenin and tigogenin inhibited proliferation and induced apoptosis of human RA FLS but tigogenin was more effective than hecogenin. Saponin-induced apoptosis was caspase dependent but PARP independent and characterized by DNA fragmentation. Our results show hecogenin- and tigogenin-induced apoptosis through p38 activation without an effect on JNK and ERK pathways. Indeed, pretreatment with a p38 inhibitor decreased saponin-induced apoptosis with a significant decrease in DNA fragmentation in human RA FLS.

Furthermore, the rate of apoptosis induced by hecogenin or tigogenin was associated with overexpression of COX-2 correlated with overproduction of endogenous $\mathrm{PGE}_{2}$. Tigogenin was more effective than hecogenin for the inhibition of proliferation, activation of caspase- 3 activity and DNA fragmentation, but we also demonstrated that tigogenin was more effective than hecogenin in stimulating COX-2 expression and activity.

\section{Materials and methods}

Materials. Dulbecco's modified Eagle's medium (DMEM), fetal calf serum (FCS) and penicillin-streptomycin were supplied by Gibco BRL (Cergy Pontoise, France). Collagenase was obtained from Worthington Biochemical Corp. (Halls Mill Road, Freehold, NJ, USA). Dispase, hyaluronidase, DNase I, hecogenin ( $5 \alpha$-spirostan-3ß-ol-12-one), tigogenin [(25R)-5 $\alpha$-spirostan-3(-ol)], 3-(4,5-dimethylthiazol-2-yl)-2,5diphenyltetrazolium bromide (MTT) and monoclonal antibody ß-actin were purchased from Sigma (Saint Quentin Fallavier, France). PARP and COX-2 monoclonal antibodies were supplied by Santa Cruz Biotechnology (TEBU, Le Perray en Yvelines, France). Cell Death Detection ELISA ${ }^{\text {PLus }}$ was supplied by Roche Diagnostics (Meylan, France). ELISA kits for $\mathrm{PGE}_{2}$ were purchased from Cayman Chemical (SpiBio, Massy, France). Recombinant human IL-1ß and Phospho-ERK1/ERK2, Phospho-JNK and Phospho-p38 $\alpha$ DuoSet IC ELISA were purchased from R\&D Systems (Lille, France). SB203580 was purchased from Calbiochem (VWR, Fontenay-sous-Bois, France).

Preparation of human synovial cells. RA synoviocytes were isolated from fresh synovial biopsies obtained from five RA patients undergoing hip arthroplasty. All patients fulfilled the
1987 American Rheumatism Association criteria for RA (19). The mean age of the patients was $60.9 \pm 3.1$ years (range, 57-64 years) and the mean disease duration was $7.9 \pm 2.9$ years. At the time of surgery, the disease activity score (DAS 28) was $>3.2$. The study protocol was approved by the local institutional review boards, and all subjects gave written informed consent. Synovia were minced and digested with $1.5 \mathrm{mg} / \mathrm{ml}$ collagenase-dispase, $1 \mathrm{mg} / \mathrm{ml}$ hyaluronidase and $0.15 \mathrm{mg} / \mathrm{ml} \mathrm{DNase} \mathrm{I} \mathrm{for} 3-4 \mathrm{~h}$ at $37^{\circ} \mathrm{C}$ as previously described (20). After centrifugation, cells were re-suspended in DMEM supplemented with 10\% FCS, $4.5 \mathrm{~g} / \mathrm{l} \mathrm{D}$-glucose, $25 \mathrm{mM}$ HEPES, $100 \mathrm{U} / \mathrm{ml}$ penicillin and $100 \mu \mathrm{g} / \mathrm{ml}$ streptomycin (Gibco BRL) in a humidified atmosphere containing $5 \%(\mathrm{v} / \mathrm{v}) \mathrm{CO}_{2}$ at $37^{\circ} \mathrm{C}$.

After $48 \mathrm{~h}$, non-adherent cells were removed. Adherent cells (macrophage-like and fibroblast-like synoviocytes, FLS) were cultured in complete medium and, at confluence, cells were trypsinized and only FLS were passed. These cells were used between passages 4 and 8 when they morphologically resembled FLS after indirect immunofluorescence study. RA FLS were cultured 45-60 days prior to experimentation. This delay eliminated all possible interactions resulting from a pre-operative treatment (NSAIDs, analgesics, DMARDs or steroids).

Culture of human RA FLS. RA FLS were trypsinized between passages 4 and 8 . Cell count and viability were determined, and cells were plated in culture plates or flasks (Sarstedt, Orsay France). Viability, measured by trypan blue dye exclusion at the start and the end of culture, was always $>95 \%$. RA FLS $\left(10^{5}\right)$ from RA patients were used for indirect immunofluorescence as previously described (16).

For all experiments, RA FLS were allowed to adhere and grow for $48 \mathrm{~h}$ in culture medium prior to exposure to 10 and $40 \mu \mathrm{M}$ hecogenin or tigogenin. A stock solution of $10^{-2} \mathrm{M}$ hecogenin or tigogenin was prepared in ethanol and diluted in culture medium to give a final concentration of 10 and $40 \mu \mathrm{M}$. The same amount of ethanol $(<0.5 \%)$ was added to control cells. After treatment, culture medium was not changed during the entire study.

Human RA FLS proliferation and light microscopy. Measurement of cell proliferation was determined using the MTT assay. Cells $\left(10^{3}\right.$ cells/well) were plated in $96-$ well culture plates and grown $48 \mathrm{~h}$ before treatment with 10 and $40 \mu \mathrm{M}$ hecogenin or tigogenin for $24-96 \mathrm{~h}$. MTT was carried out daily as previously described (21) and experiments were performed in six duplicate assays.

For light microscopy, after $24 \mathrm{~h}$ of treatment, RA FLS cultured cells were fixed in phosphate-buffered saline (PBS) ( $\mathrm{pH} 7.4$ ) containing $4 \%$ paraformaldehyde for $20 \mathrm{~min}$ at room temperature and washed in PBS for $15 \mathrm{~min}$. Observations were realized with phase-contrast microscopy.

Caspase- 8 and caspase- 9 activity assays. Caspase- 8 and caspase- 9 activities were respectively assayed using caspase- 8 and caspase-9 colorimetric assay (R\&D Systems). RA FLS cells were cultured in $75 \mathrm{~cm}^{2}$ flasks and treated or not with $40 \mu \mathrm{M}$ hecogenin or tigogenin for $30 \mathrm{~min}, 2 \mathrm{~h}$ and $6 \mathrm{~h}$. Cells were first lysed to collect their intracellular contents. 
The cell lysate was then tested for protease activity by the addition of a caspase-specific peptide that is conjugated to the color reporter molecule p-nitroalanine (pNA). Cleavage of the peptide by the caspase releases the chromophore pNA, which can be quantified spectrophotometrically at a wavelength of $405 \mathrm{~nm}$. The level of caspase enzymatic activity in the cell lysate is directly proportional to the color reaction.

Caspase-3 activity assay. Caspase-3 activity was assayed using Quantikine ${ }^{\circledR}$ human active caspase-3 (R\&D Systems) as previously described (22). Following the same treatments as those used for caspase- 8 and caspase- 9 activity detection, human RA FLS were incubated with $10 \mu \mathrm{M}$ biotin-ZVKDfmk inhibitor for $1 \mathrm{~h}$ at $37^{\circ} \mathrm{C}$. Caspase-3 activity was then measured in accordance with the manufacturer's protocol (R\&D Systems). Briefly, cells were harvested, washed in PBS and re-suspended in extraction buffer containing protease inhibitors. Standards and sample extracts containing covalently linked active caspase-3-ZVKD-biotin were added to a microplate pre-coated with monoclonal antibody specific for caspase-3. Then, streptavidin conjugated to horseradish peroxidase was added to the wells. The amount of active caspase-3 was quantified by colorimetry at $450 \mathrm{~nm}$ after addition of the HRP substrate.

Apoptosis quantification: DNA fragmentation. Human RA FLS were cultured in 6 -well culture plates $\left(2 \times 10^{5}\right.$ cells/well). Cells were treated without or with $40 \mu \mathrm{M}$ hecogenin or tigogenin alone for 12 and $24 \mathrm{~h}$, or pre-incubated for $2 \mathrm{~h}$ with $10 \mu \mathrm{M}$ SB203580 (p38 inhibitor) before addition of $40 \mu \mathrm{M}$ hecogenin or tigogenin for $24 \mathrm{~h}$. Apoptosis was quantified on pooled cells (floating and adherent) using the 'cell death' ELISA (Cell Death Detection ELISA ${ }^{\text {PLUS }}$ ). Cytosol extracts were obtained according to the manufacturer's protocol and apoptosis was measured as previously described (16).

Quantification of human phospho-ERK1/ERK2, phospho$J N K$ and phospho-p38a. Human RA FLS were grown in $25 \mathrm{~cm}^{2}$ tissue culture flasks for $48 \mathrm{~h}$ before treatment. After washing with $\mathrm{PBS}$ ( $\mathrm{pH} 7.4$ ), cells were incubated at $37^{\circ} \mathrm{C}$ with $40 \mu \mathrm{M}$ hecogenin or tigogenin for $20 \mathrm{~min}, 1 \mathrm{~h}, 6 \mathrm{~h}$ and $24 \mathrm{~h}$ or with interleukin (IL)-1ß (1 ng/ml) alone for $20 \mathrm{~min}$ as a positive control. After treatment, $10^{6}$ cells were homogenized in lysis buffer in accordance with the manufacturer's protocol (R\&D Systems). Before assay, one plate was coated with $100 \mu 1$ per well of capture antibody $(4 \mu \mathrm{g} / \mathrm{ml})$ overnight at room temperature. The plate was washed three times with $400 \mu 1$ wash buffer and blocked by adding $300 \mu 1$ blocking buffer to each well for 1-2 $\mathrm{h}$ at room temperature. Before use, cell lysates were centrifuged at $2000 \mathrm{x} g$ for $5 \mathrm{~min}$ and supernatants were diluted 6-fold. Phospho-ERK1/ERK2, phosphoJNK or phospho-p38 $\alpha$ detection was performed according to the manufacturer's instructions (R\&D Systems) as previously described (23).

COX-2 expression analysis. Human RA FLS were cultured in $150 \mathrm{~cm}^{2}$ tissue culture flasks. After a $40 \mu \mathrm{M}$ hecogenin or tigogenin treatment for $30 \mathrm{~min}, 2 \mathrm{~h}$ and $24 \mathrm{~h}$, adherent cells were trypsinized and pooled with the floating cell fraction. Western blot analysis was performed as previously described

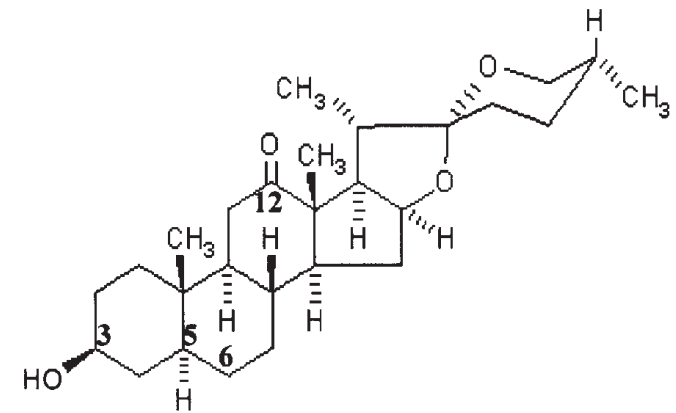

\section{hecogenin}

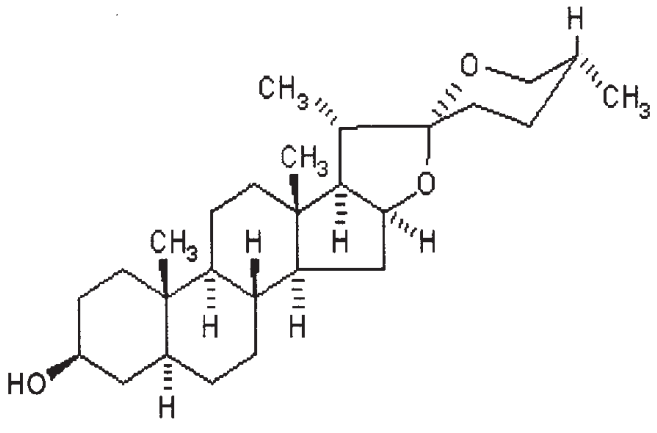

tigogenin

Figure 1. Molecular structure of the hecogenin and tigogenin molecules.

(24) using the primary monoclonal antibodies $\beta$-actin (mouse anti-human B-actin, 1:5000; Sigma), PARP (mouse antihuman PARP, 1:100; Santa Cruz Biotechnology), COX-2 (mouse anti-human COX-2, 1:100; Santa Cruz Biotechnology) and secondary polyclonal antibody conjugated with peroxidase (Dako). Blots were visualized using enhanced chemiluminescence reagents (Amersham Biosciences) and immediately exposed to X-ray film.

Assay of $\mathrm{PGE}_{2}$ production. Human RA FLS were grown in $25 \mathrm{~cm}^{2}$ tissue culture flasks for $48 \mathrm{~h}$ before treatment. After washing with PBS ( $\mathrm{pH} 7.4$ ), cells were treated for 2 and $24 \mathrm{~h}$ at $37^{\circ} \mathrm{C}$ with $40 \mu \mathrm{M}$ hecogenin or tigogenin in DMEM containing $10 \%(\mathrm{v} / \mathrm{v}) \mathrm{FCS}$ in a $5 \% \mathrm{CO}_{2}$ atmosphere. The $\mathrm{PGE}_{2}$ concentration in the medium was measured using an ELISA kit according to the instructions of the manufacturer (Cayman Chemical) and was normalized with respect to the number of viable cells present in the particular culture at the time of sampling.

Statistical analysis. The median and standard deviation (SD) were calculated using Excel (Microsoft Office, version 98). Statistical analysis of differences was carried out by analysis of variance (ANOVA) using StatView version 5.0 (SAS Institute Inc, Cary, NC, USA). A p-value $<0.05$ [Fisher's Protected Least Significant Difference (PLSD) test] was considered to indicate significant differences.

\section{Results}

The effect of hecogenin and tigogenin on human RA FLS proliferation and morphological modifications. Cells were 
A

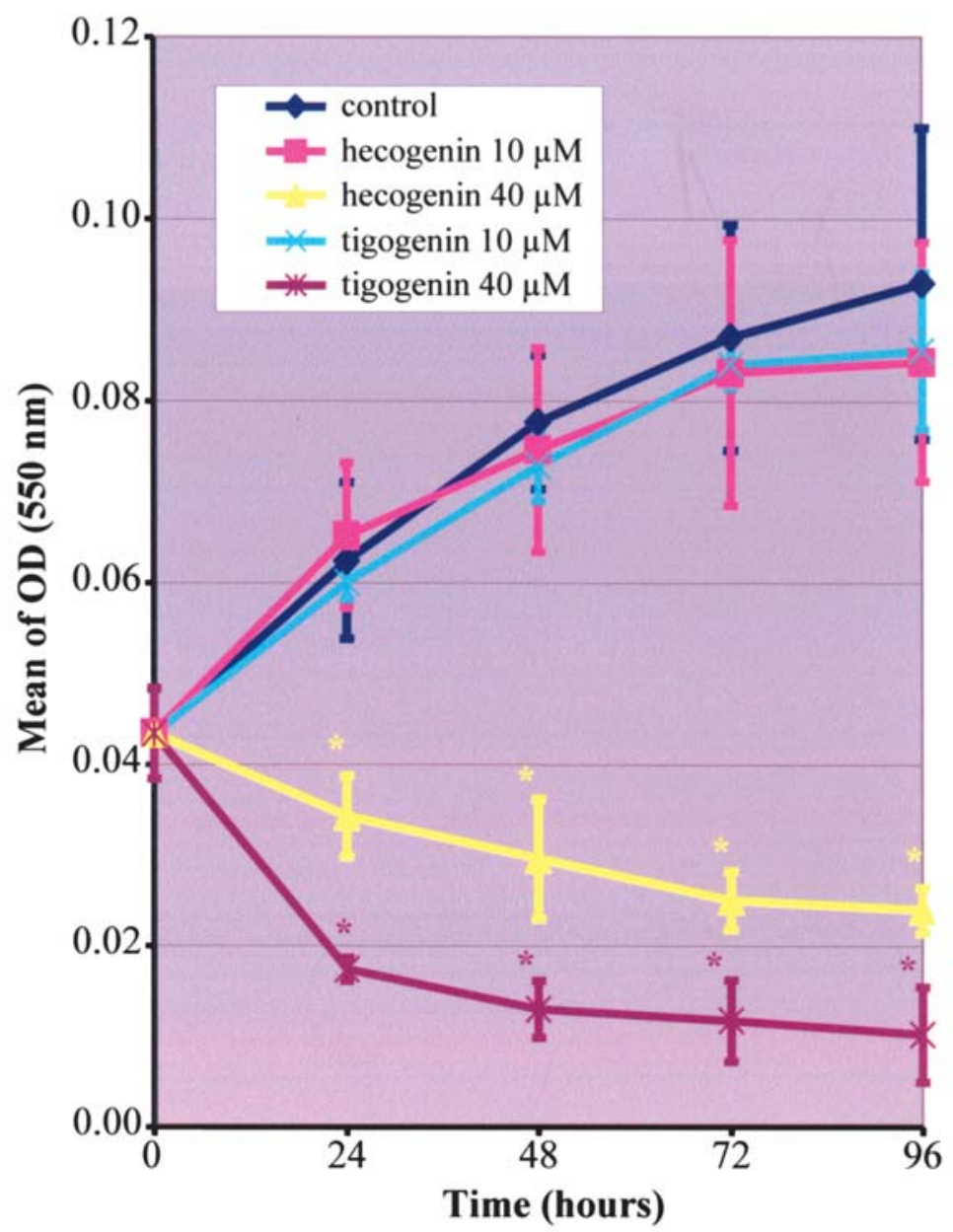

B
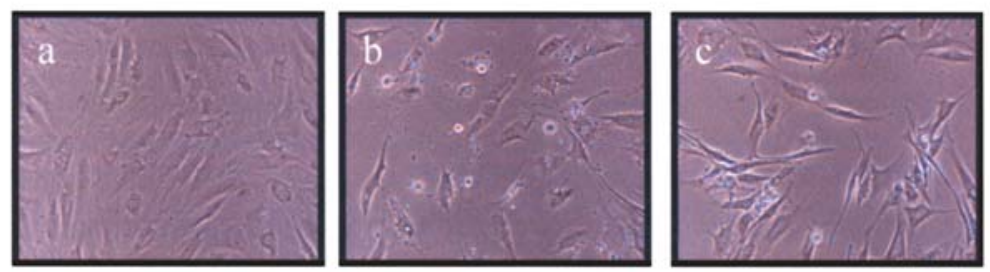

Figure 2. (A) Effect of hecogenin and tigogenin on proliferation of human RA FLS. Cells were cultured in 10\% FCS medium for $48 \mathrm{~h}$ and then incubated (time 0) for 24-96 h with saponin at 10 and $40 \mu \mathrm{M}$. RA FLS proliferation was evaluated by the MTT test. Measurements were made on FLS from five different patients. Representative results from six independent experiments are shown; values are the mean \pm SD from triplicate cultures. " $\mathrm{p}<0.05$ (Fisher's PLSD test) was considered to indicate significant differences compared to the control. (B) Morphologic changes in human RA FLS. Cells were incubated for $24 \mathrm{~h}$ without (a) or with $40 \mu \mathrm{M}$ hecogenin (b) or tigogenin (c). Original magnification, $\mathrm{x} 400$.

cultured in $10 \%$ FCS-medium with or without 10 and $40 \mu \mathrm{M}$ hecogenin or tigogenin (Fig. 1) for 24-96 h, and cell proliferation was evaluated by the MTT test (Fig. 2A). Under our experimental conditions, a decrease in proliferation was observed up to $24 \mathrm{~h}$ after hecogenin and tigogenin treatment $(40 \mu \mathrm{M})$, especially at $24 \mathrm{~h}$ for tigogenin when the percentage of inhibition was $-69 \%(\mathrm{p}<0.05)$ compared to $-46 \%(\mathrm{p}<0.05)$ for hecogenin (Fig. 2A). Proliferation of human RA FLS decreased until $96 \mathrm{~h}(-75 \%$ and $-89 \%$, $\mathrm{p}<0.05)$ in the presence of $40 \mu \mathrm{M}$ hecogenin or tigogenin respectively. An antiproliferative effect was not observed for these two saponins at $10 \mu \mathrm{M}$ compared to the control (Fig. 2A). For this reason, we chose $40 \mu \mathrm{M}$ for treatment in subsequent experiments.
Direct observation with phase-contrast microscopy demonstrated that human RA FLS treated with $40 \mu \mathrm{M}$ hecogenin or tigogenin for $24 \mathrm{~h}$ (Fig. 2B, b and c) showed numerous morphological differences compared to control cells (Fig. 2B, a). Indeed, cell shrinkage, cytoplasm condensation and formation of cytoplasmic filaments appeared after $40 \mu \mathrm{M}$ of saponin treatment for $24 \mathrm{~h}$.

Apoptosis induced by hecogenin or tigogenin was caspase dependent and PARP independent. Induction of apoptosis requires activation of specific proteins. It is well known that apoptosis is characterized by chromatin condensation and DNA fragmentation, and is mediated by the cysteine protease family called caspases, such as caspase-3, which is the major 

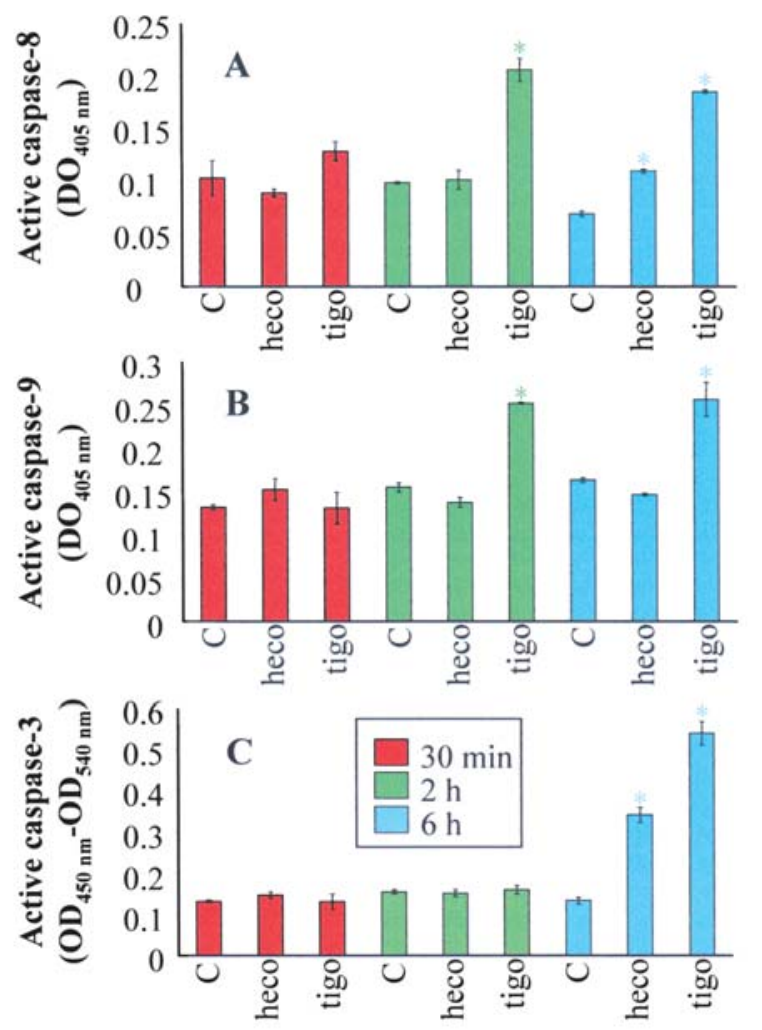

D

\begin{tabular}{|c|c|c|}
\hline & $\mathbf{1 2} \mathbf{~ h}$ & $\mathbf{2 4} \mathbf{~}$ \\
\hline control & 1 & 1 \\
\hline hecogenin & $1.9 \pm 0.1^{*}$ & $3.2 \pm 0.9^{\sharp}$ \\
\hline tigogenin & $2.5 \pm 0.1^{*}$ & $6.8 \pm 0.9^{\sharp}$ \\
\hline
\end{tabular}

Figure 3. Effect of hecogenin and tigogenin on initiator caspase-8 and caspase-9 activities, central effector caspase- 3 activity and DNA fragmentation in human RA FLS. RA FLS cells were cultured in $75 \mathrm{~cm}^{2}$ flasks and treated or not with $40 \mu \mathrm{M}$ hecogenin (heco) or tigogenin (tigo) for $30 \mathrm{~min}, 2 \mathrm{~h}$ and $6 \mathrm{~h}$. Caspase- 8 (A) and caspase-9 (B) activities were respectively assayed using caspase- 8 and caspase- 9 colorimetric assay (R\&D Systems) and quantitated spectrophotometrically at a wavelength of $405 \mathrm{~nm}$. Caspase-3 activity (C) was assayed using Quantikine ${ }^{\circledR}$ human active caspase-3 (R\&D Systems). Following the same treatments as those used for caspase- 8 and caspase- 9 activity detection, human RA FLS were incubated with $10 \mu \mathrm{M}$ biotin-ZVKD-fmk inhibitor for $1 \mathrm{~h}$ at $37^{\circ} \mathrm{C}$. The amount of active caspase- 3 was quantified by colorimetry at $450 \mathrm{~nm}$. Values are expressed as the mean $\pm \mathrm{SD}$ and one representative of three independent experiments is shown. Apoptosis was quantified on floating and adherent cells using 'cell death' ELISA based on DNA fragmentation (D). The fold induction of DNA fragmentation is shown relative to the value for the control (C) culture, which was equated to 1 . Data are expressed as the mean \pm SD of three experiments from three different patients. * "\# $\mathrm{p}<0.05$ (Fisher's PLSD test) was considered to indicate significant differences compared to controls.

executioner of apoptosis. PARP is one of the best known caspase substrates and its inactivation by cleavage is now an apoptosis hallmark. DNA fragmentation occurs simultaneously with this phenomenon and is now considered as a major marker of apoptotic cells.

First, we studied caspase- 8 activity, the central initiator caspase in the extrinsic (death receptor) pathway, and caspase- 9 activity, the central initiator caspase in the intrinsic (mitochondrial) pathway. Our results showed that only tigogenin induced both caspase- 8 and caspase- 9 activities after $2 \mathrm{~h}$ of treatment (2.1- and 1.6-fold increases respectively versus control, $\mathrm{p}<0.05$ ) (Fig. $3 \mathrm{~A}$ and $\mathrm{B}$ ). After $6 \mathrm{~h}$ of treatment, hecogenin activated caspase-8 (1.6-fold increase versus control, $\mathrm{p}<0.05)$ but tigogenin treatment provoked a more pronounced effect (2.6-fold versus control, $\mathrm{p}<0.05$ ) (Fig. 3A). Furthermore, the activation of caspase-9 by tigogenin was always significant after $6 \mathrm{~h}$ of treatment $(1.5-$ fold increase versus control, $\mathrm{p}<0.05)$ whereas the effect of hecogenin was caspase- 9 independent over time in human RA FLS (Fig. 3B).

Following activation of both initiator caspases, we showed that both saponins (hecogenin and tigogenin) induced executive caspase-3 activity after $6 \mathrm{~h}$ of treatment (Fig. 3C). Activation of caspase- 3 by hecogenin was increased 2.5 -fold versus control $(\mathrm{p}<0.05)$. Caspase- 3 activation was greater in the presence of tigogenin $(4.0$-fold versus control, $\mathrm{p}<0.05)$.

Surprisingly, the activation of caspase- 3 was not followed by cleavage of PARP after treatment with hecogenin or tigogenin. Western blotting detected the native form $(112 \mathrm{kDa})$ of PARP but not the cleaved fragment at $85 \mathrm{kDa}$ in untreated or treated human RA FLS (data not shown).

However, DNA fragmentation, considered as a major marker of apoptotic cells, has been observed in human RA FLS after hecogenin or tigogenin treatment. Quantitative determination of cytoplasmic histone-associated DNA fragments (mononucleosomes and oligonucleosomes) was performed with ELISA in our study. Results showed that DNA fragmentation was induced in cells as early as $12 \mathrm{~h}$ after hecogenin or tigogenin treatment (1.9-and 2.5-fold increases respectively versus control, $\mathrm{p}<0.05)$ but DNA fragmentation was markedly increased at $24 \mathrm{~h}$ (3.2-fold for hecogenin and 6.8-fold for tigogenin versus control, $\mathrm{p}<0.05)$ (Fig. 3D).

Involvement of MAPKs in hecogenin- or tigogenin-induced apoptosis in human RA FLS. MAPKs represent an attractive target for RA treatment because they can regulate cell proliferation and apoptosis. It has been reported that JNK/p38 MAPK and ERK play opposite roles in apoptosis induction in such a way that the former promotes apoptosis induction whereas the latter inhibits it. In order to elucidate potentially different actions of the three groups of MAPKs in human RA FLS, we studied saponin-triggered MAPK signal transduction cascades in relation to apoptosis induction. We showed that $40 \mu \mathrm{M}$ hecogenin activated p38 as early as $1 \mathrm{~h}$ in human RA FLS (1.4-fold increase versus control, p<0.05) with a maximum at $6 \mathrm{~h}(2.0$-fold versus control, $\mathrm{p}<0.05)$ and 1.5 -fold at $24 \mathrm{~h}$ versus control $(\mathrm{p}<0.05)$ (Fig. 4A, a). Furthermore, $40 \mu \mathrm{M}$ tigogenin more strongly activated p38 as early as $1 \mathrm{~h}$ (2.0-fold increase versus control, $\mathrm{p}<0.05)$ and at $6 \mathrm{~h}(1.9$-fold versus control, $\mathrm{p}<0.05)$ with a maximum at $24 \mathrm{~h}(2.3$-fold versus control, $\mathrm{p}<0.05$ (Fig. 4A, a). However, both saponins had no effect on JNK and ERK phosphorylation over time in human RA FLS (Fig. 4A, b and c respectively). IL-1B treatment for 20 min served as a positive control of MAPK activation.

In the present study, we investigated whether or not p38 was implicated in the apoptotic signalling pathway of 
A
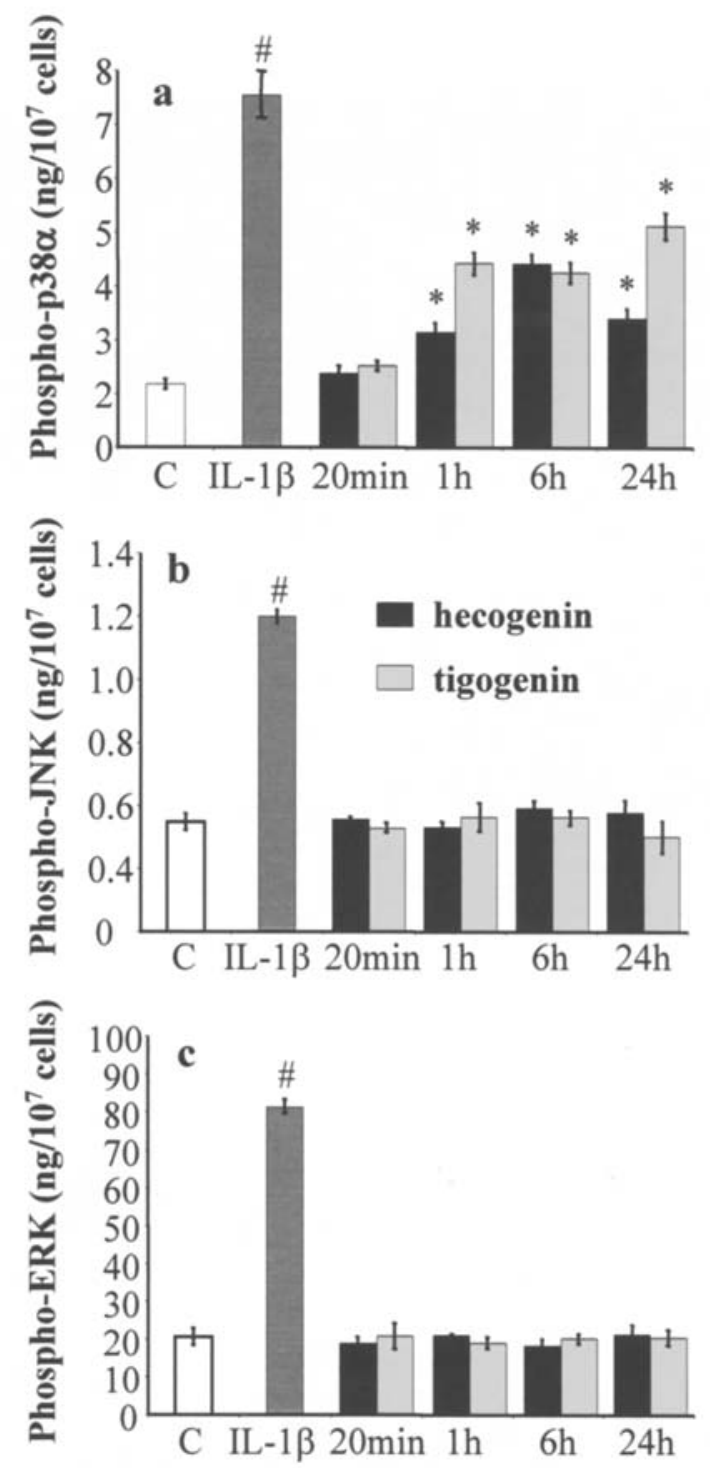

hecogenin and tigogenin in human RA FLS. We chose to study DNA fragmentation, a final step of apoptosis. Results showed that DNA fragmentation was reduced in human RA FLS pretreated with a specific inhibitor of transducing apoptotic factor p38 (Fig. 4B). Indeed, $10 \mu \mathrm{M}$ of SB203580 pretreatment for $2 \mathrm{~h}$ before addition of $40 \mu \mathrm{M}$ hecogenin or tigogenin decreased DNA fragmentation of human RA FLS (-48 and $-44 \%$ respectively versus hecogenin or tigogenin alone) (Fig. 4B).

Upregulation of COX-2 expression and activity in saponininduced RA FLS death. Numerous current studies have demonstrated that COX-2 expression prevents apoptosis in cancer cells, especially in colon cancer. In contrast to other cell types, the effects of COX-2 and related $\mathrm{PGE}_{2}$ in the regulation of apoptosis could very well be cell type specific. Here, we demonstrated that hecogenin or tigogenin induced COX-2 overexpression over time (Fig. 5A). Indeed, our results showed induction of COX-2 expression as early as $2 \mathrm{~h}$ after treatment with $40 \mu \mathrm{M}$ hecogenin or tigogenin and the expression of COX-2 was markedly enhanced at $24 \mathrm{~h}$ after
B

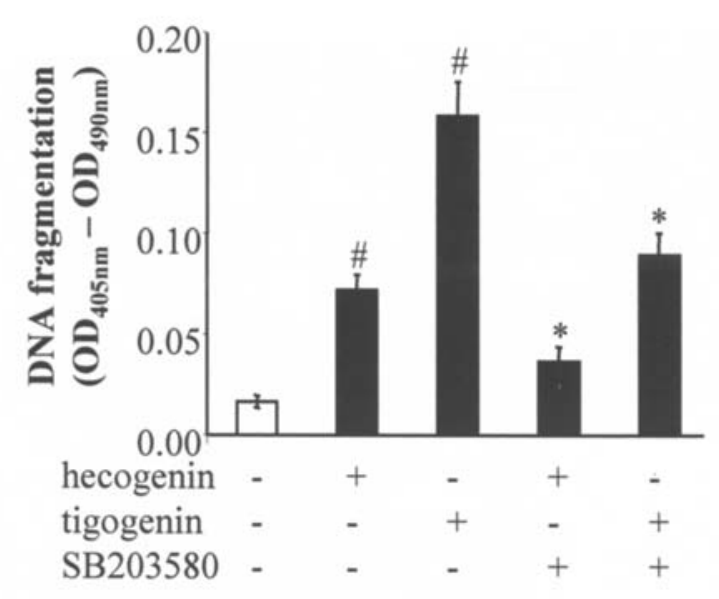

Figure 4. Different contribution of the p38 pathway (A,a) compared to JNK $(\mathrm{A}, \mathrm{b})$ and ERK $(\mathrm{A}, \mathrm{c})$ pathways on hecogenin- or tigogenin-induced RA FLS apoptosis. Human RA FLS were incubated without (control, C) or with $40 \mu \mathrm{M}$ hecogenin or tigogenin for $20 \mathrm{~min}, 1 \mathrm{~h}, 6 \mathrm{~h}$ and $24 \mathrm{~h}$ or with IL-1ß (1 $\mathrm{ng} / \mathrm{ml}$ ) alone for $20 \mathrm{~min}$ as a positive control. Cells were lysed, and phosphorylated MAPKs were quantified with the DuoSet ${ }^{\circledR}$ IC assay kits (R\&D Systems). The respective DuoSet IC assay kits contained the basic components required for the development of sandwich ELISAs to measure natural and recombinant phospho-ERK1 (T202/Y204) and phospho-ERK2 (T185/Y187), JNK1 and JNK2 dually phosphorylated at T183/Y185 and phospho-JNK3 (T221/Y223), and phospho-p38 a (T180/Y182) in cell lysates. RA FLS from three different patients were used for quantification. Data are expressed as the mean $\pm \mathrm{SD}$ of three experiments. One representative experiment out of three is presented. ${ }^{*} \mathrm{p}<0.05$ and ${ }^{*} \mathrm{p}<0.01$ (Fisher's PLSD test) were considered to indicate significant differences compared to untreated cell control. (B) Cells were treated without or with $40 \mu \mathrm{M}$ hecogenin or tigogenin alone for $24 \mathrm{~h}$, or pre-incubated for $2 \mathrm{~h}$ with $10 \mu \mathrm{M}$ SB203580 (p38 inhibitor) before addition of $40 \mu \mathrm{M}$ saponin for $24 \mathrm{~h}$. Apoptosis was quantified on pooled cells (floating and adherent) by the Cell Death Detection ELISA ${ }^{\text {PLUS }}$. Measurements were made on FLS from four different patients. Data are expressed as the mean \pm SD of four experiments. ${ }^{*} \mathrm{p}<0.01$ and ${ }^{*} \mathrm{p}<0.05$ (Fisher's PLSD test) were considered to indicate significant differences compared to untreated cell control or hecogenin or tigogenin alone respectively. OD, optical density. saponin treatment with a large difference in COX-2 overexpression between hecogenin and tigogenin (Fig. 5A).

This overexpression was correlated with COX-2 activity. $\mathrm{PGE}_{2}$ production was increased over time after saponin treatment; 2.0- and 2.7-fold for hecogenin and tigogenin respectively $(\mathrm{p}<0.05)$ at $2 \mathrm{~h}$ and 3.3 - and 5.3 -fold respectively $(\mathrm{p}<0.05)$ at $24 \mathrm{~h}$ compared to the control (Fig. 5B).

\section{Discussion}

Saponins have drawn scientific attention due to their structural diversity and the significance of their biological activities. Some studies have revealed that differences in saponin structure including the type and number of sugar moieties attached by a glycosidic bond at C-3 (Fig. 1) influence biological responses $(25,26)$. Wang et al $(27)$ compared dioscin, a spirostenol (diosgenin-3- $O$-( $\alpha$-L-rhamnopyranosyl $(1->2))(\alpha-L-$-rhamnopyranosyl(1->4))), and methyl protodioscin, a furostanol with 26-O-glycopyranoside. These authors showed that only dioscin induces apoptosis although these 

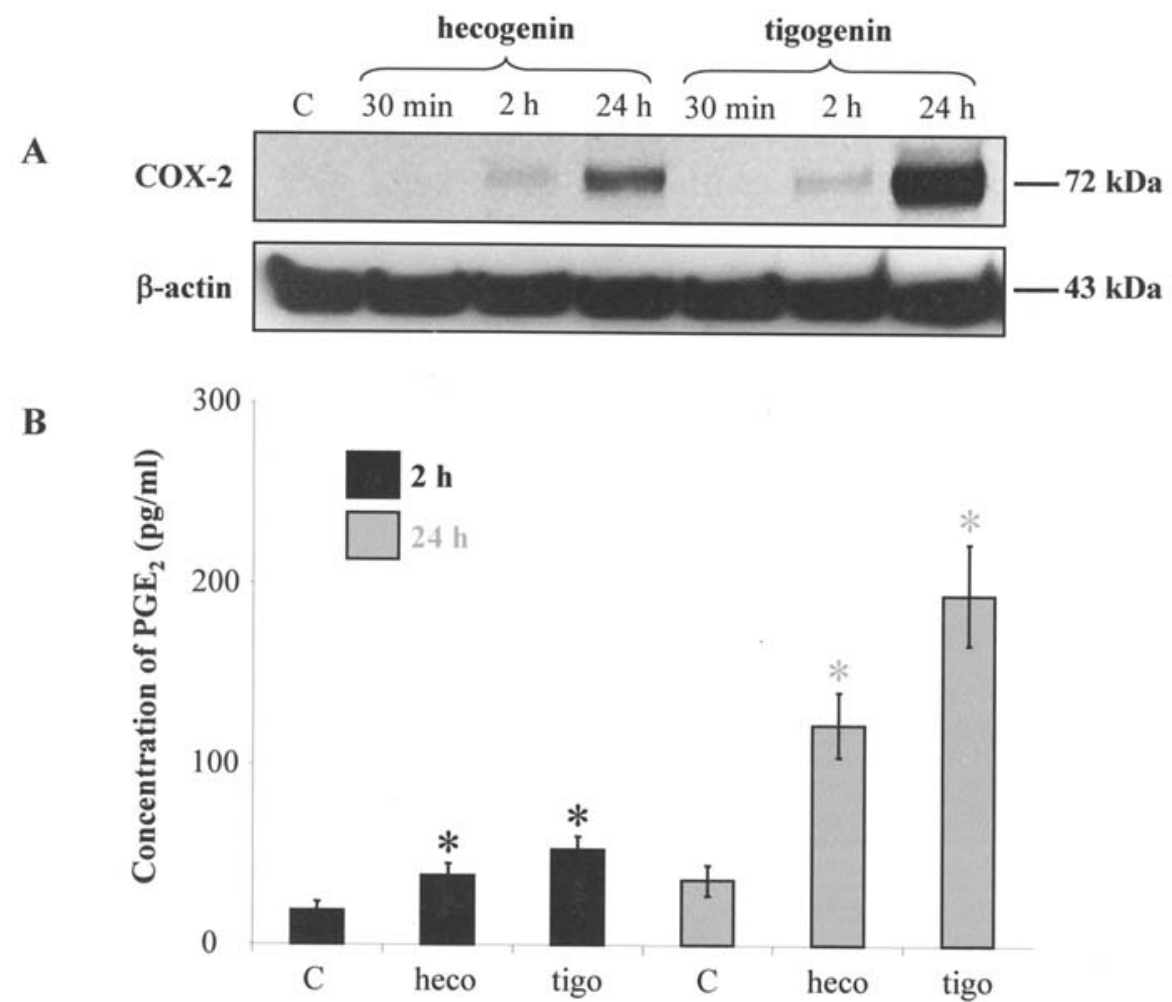

Figure 5. COX-2 expression (A) and activity (B) in hecogenin- or tigogenin-induced RA FLS apoptosis. Cells were cultured without saponin (C, control) or were incubated with $40 \mu \mathrm{M}$ hecogenin (heco) or tigogenin (tigo) for $30 \mathrm{~min}, 2 \mathrm{~h}$ and $24 \mathrm{~h}$. Protein extracts prepared from cells were subjected to Western blotting and cellular expressions of COX-2 and $\beta$-actin were estimated using mouse anti-human COX-2 and B-actin antibodies respectively as described in Materials and methods. Quantification of each band was performed by densitometry analysis software. One of three representative experiments is shown from three different patients. The $\mathrm{PGE}_{2}$ levels in the culture medium were measured by enzyme immunoassay. Cells were cultured in $10 \%$ FCS medium for $48 \mathrm{~h}$ and then treated or not (C, control) with $40 \mu \mathrm{M}$ hecogenin or tigogenin for 2 and $24 \mathrm{~h}$. Measurements were made on FLS from four different patients. Data are expressed as the mean \pm SD of four experiments. ${ }^{*} \mathrm{p}<0.05$ (Fisher's PLSD test) was considered to indicate significant differences compared to the controls.

two compounds are structurally similar. They suggested that the structure of the spirostenol must play a critical role in the activity of dioscin.

From our previous studies $(17,18)$, we already speculated that the 5,6-double bond probably plays a significant role in biological effects. In the present study, we decided to focus on this structural characteristic to shed light on the reactivity of this site in apoptosis, MAPK pathways and COX-2 expression. Recently, we described, for the first time, that diosgenin induced apoptosis in human RA FLS with COX-2 expression (16) but also inhibited the activation of survival transducing factors such as ERK while activating apoptotic transducers such as p38 and JNK (28). The aim of our study was to compare hecogenin and tigogenin [lacking the 5,6-double bond compared to diosgenin (18)] with our previous results concerning diosgenin $(16,28)$. Hecogenin and tigogenin only differ in the presence or absence respectively of a keto group at C-12 (Fig. 1).

Hecogenin and tigogenin inhibited human RA FLS proliferation and this effect was more pronounced for tigogenin. Our study also showed that cells treated with both saponins became rounder, exhibited shrinkage, and separated from adjacent cells. Plant steroids have been thoroughly described for their pharmacological properties, including hypocholesterolemic, antidiabetic and antioxidant activities. Particular attention has been given to their potential for cancer chemoprevention, especially as apoptosis inducers (29). It is of great importance to understand the mechanisms of apoptosis in RA, as impaired apoptosis in synovial cells is closely associated with hyperplasia of synovial tissues found in patients with RA (30).

Apoptosis is a highly orchestrated and controlled form of cell death, distinct from the pathologic process of necrosis that occurs as a result of cellular damage. Apoptosis involves specific initiating stimuli and intracellular signals, and requires expression of a well-defined set of genes that accomplish the cellular program. In general, apoptosis involves sequential activation of a proteolytic cascade of enzymes named caspases (31). Caspase-3 activation is considered as a convenient marker of apoptosis and is regarded as the point of no return in the proapoptotic signalling cascade (32). In our study, we showed that only tigogenin induced both caspase- 8 (extrinsic pathway) and caspase- 9 (intrinsic pathway) activities. Hecogenin only induced caspase- 8 activity. Consequently, RA FLS death was clearly related to the activation of the caspase cascade, as both saponins increased caspase- 3 activity. We showed that caspase-3 activity was greater after tigogenin treatment in relationship with synergistic activation of upstream cysteine protease caspase- 8 and -9 than after hecogenin treatment. However, caspase- 3 activation by both saponins was not followed by cleavage of its substrate PARP. These results suggested that hecogenin and tigogenin induced cell death in human RA FLS via caspase-3-dependent and PARP- 
independent mechanisms. Furthermore, RA FLS apoptosis induced by hecogenin or tigogenin was quantified by determination of cytoplasmic histone-associated DNA fragments. The apoptotic ratio, determined by ELISA, significantly increased over time for cells treated with saponins. A correlation was shown between the level of caspase-3 activity and DNA fragmentation as a function of the saponin used.

It has been reported that JNK/p38 MAPK and ERK play opposite roles in apoptosis induction in such a way that the former promotes apoptosis induction whereas the latter inhibits it (33). Based on these data and our previous results (18), we studied the effect of hecogenin and tigogenin on the activation of survival (ERK) or proapoptotic (p38, JNK) transducing factors in relation to apoptosis in human RA FLS in vitro. MAPKs represent an attractive target for RA treatment because they can regulate cell proliferation, apoptosis (34), cytokine expression $(35,36)$ and metalloproteinase production (37). These MAPKs are expressed in synovial tissue and in cultured FLS $(38,39)$. Treatment of cells with $40 \mu \mathrm{M}$ hecogenin or tigogenin caused p38 activation but had no effect on JNK and ERK phosphorylation. IL-1ß treatment, which is known to induce MAPK phosphorylation (40), served as a positive control. Recently, Yen et al (41) reported that diosgenin promoted angiogenesis in preosteoblast-like cells by a hypoxiainducible factor- $1 \alpha$-dependent mechanism involving the activation of p38 MAPK. Our recent study showed that, diosgenin $(40 \mu \mathrm{M})$ inhibited ERK activation but activated p38 and JNK in human erythroleukemia (HEL) cells (22) but also in human RA FLS (28).

At this stage of our study, we showed that three structurally similar saponins caused apoptosis of synovial cells but with different signalling pathways compared with results previously described for diosgenin (28) where three MAPK pathways were implicated; hecogenin or tigogenin induced apoptosis only by the p38 pathway. To confirm the implication of the p38 kinase signalling pathway in hecogenin- or tigogenininduced apoptosis in human RA FLS, we used a specific inhibitor for pretreatment before addition of saponins. After quantitative determination of cytoplasmic histone-associated DNA fragments (mononucleosomes and oligonucleosomes) by ELISA, our results showed that SB203580 reduced hecogenin- or tigogenin-induced DNA fragmentation. These findings provide evidence that hecogenin and tigogenin $(40 \mu \mathrm{M})$ promote apoptosis in human RA FLS by a mechanism involving p38 activation.

RA is characterized by the proliferation of synoviocytes which also produce prostanoids. Eicosanoids and prostanoids are important lipid mediators that are produced at elevated levels in inflamed tissues including rheumatoid synovium and in cultured human RA FLS (20,42-44). Curiously, we showed that the level of apoptosis in RA FLS treated with diosgenin seemed to be associated with upregulation of COX-2 $(16,18)$ in contrast with the majority of data from other cell types such as cancer cells, in which COX-2 expression was shown to prevent apoptosis. Indeed, overexpression of COX-2 in several pathological conditions, such as colon carcinoma, point to a causative role of COX-2 in tumor initiation and/or promotion $(45,46)$. But, in the literature, this phenomenon has begun to be discussed with regards to cancer type because recently $\mathrm{Xu}$ et al (47) demonstrated that overexpression of COX-2 in human osteosarcoma cells decreased proliferation and increased apoptosis. In addition, increased $\mathrm{PGE}_{2}$ was shown to be related to the induction of apoptosis in growth plate chondrocytes (48) and, more recently, Pelletier et al (49) found that the in situ increase in chondrocyte death/apoptosis in experimental osteoarthritis was mainly caspase dependent and was influenced by upregulation of the level of COX-2. Concerning the studies on synoviocytes, it was shown that nitric oxide induced synoviocyte death through $\mathrm{COX}-2$ expression and $\mathrm{PGE}_{2}$ synthesis with a significant change in mitochondrial membrane potential associated with the activation of caspase-3 (50). These results concerning the effects of nitric oxide are in harmony with our previous study on the effects of diosgenin on RA FLS (16). Previously, we described that diosgenininduced apoptosis in human cancer cells was associated with $\mathrm{PGE}_{2}$ increased production $(24,51)$. All these studies demonstrated that the effects of COX-2 and related $\mathrm{PGE}_{2}$ in the regulation of apoptosis reflected differences in cellular responses. For this reason, our study focused on COX-2 in order to determine if hecogenin- and tigogenin-induced apoptosis in human RA FLS was also accompanied by upregulation of COX-2 as a function of molecular structure of these saponins.

Under our conditions, hecogenin and tigogenin induced COX-2 expression over time. Increased COX-2 expression was correlated with $\mathrm{PGE}_{2}$ production. We showed that tigogenin was a more potent inducer of apoptosis than hecogenin especially after $24 \mathrm{~h}$ of treatment. We demonstrated that, at this time in treatment, tigogenin had a greater effect on COX-2 expression and activity than hecogenin.

In conclusion, we showed for the first time that hecogenin and tigogenin induced apoptosis in human RA FLS in vitro. However, we characterized that these two saponins, as a function of molecular structure, induced cell death with different rates of apoptosis. Tigogenin which lacks the 5,6double bond compared to diosgenin (18) was more effective than hecogenin which lacks the 5,6-double bond but has the additional keto group at C-12, for inhibition of proliferation, for induction of caspase activities, and for DNA fragmentation. Moreover, the effect of these two molecules on apoptosis in human RA FLS was PARP independent.

Based on our previous investigations with diosgenininduced apoptosis, we confirmed that structurally similar plant steroids (hecogenin and tigogenin) induced COX-2 expression and activity in apoptotic conditions. Diosgenin induced apoptosis in human RA FLS by inhibition of ERK activation but also by activation of p38 and JNK (28). However, in the absence of the 5,6-double bond in their structures, we demonstrated that only the p38 pathway was implicated in hecogenin- and tigogenin-induced apoptosis. Indeed, this result was confirmed by using an inhibitory strategy on p38 signalling. Pretreatment with SB203580 before saponin addition reduced saponin-induced apoptosis.

Taken together, these new results provide strong evidence that a family of structurally similar plant steroids is capable of inducing apoptosis in human RA FLS with different rates 
and different signalling pathways. This study also confirms the discussed appearance of the downregulation or upregulation of COX-2 in cell apoptosis as a function of cell type.

\section{Acknowledgements}

This study was supported by grants from La Société Française de Rhumatologie. The authors acknowledge Dr Jeanne Cook-Moreau for helpful discussions in the preparation of this manuscript.

\section{References}

1. Sirtori CR, Lovati MR, Manzoni C, et al: Proteins of white lupin seed, a naturally isoflavone-poor legume, reduce cholesterolemia in rats and increase LDL receptor activity in HepG2 cells. J Nutr 134: 18-23, 2004.

2. Attele AS, Zhou YP, Xie JT, et al: Antidiabetic effects of Panax ginseng berry extract and the identification of an effective component. Diabetes 51: 1851-1858, 2002.

3. Turchan J, Pocernich CB, Gairola C, et al: Oxidative stress in HIV demented patients and protection ex vivo with novel antioxidants. Neurology 60: 307-314, 2003.

4. Priyadarshi S, Valentine B, Han C, et al: Effect of green tea extract on cardiac hypertrophy following 5/6 nephrectomy in the rat. Kidney Int 63: 1785-1790, 2003.

5. Chang LC, Tsai TR, Wang JJ, Lin CN and Kuo KW: The rhamnose moiety of solamargine plays a crucial role in triggering cell death by apoptosis. Biochem Biophys Res Commun 242: 21-25, 1998.

6. Popovich DG and Kitts DD: Structure-function relationship exists for ginsenosides in reducing cell proliferation and inducing apoptosis in the human leukemia (THP-1) cell line. Arch Biochem Biophys 406: 1-8, 2002.

7. Liang CH, Liu LF, Shiu LY, Huang YS, Chang LC and Kuo KW: Action of solamargine on TNFs and cisplatin-resistant human lung cancer cells. Biochem Biophys Res Commun 322: 751-758, 2004.

8. Hernandez JC, Leon F, Quintana J, Estevez F and Bermejo J: Icogenin, a new cytotoxic steroidal saponin isolated from Dracaena draco. Bioorg Med Chem 12: 4423-4429, 2004.

9. Haddad M, Laurens V and Lacaille-Dubois MA: Induction of apoptosis in a leukemia cell line by triterpene saponins from Albizia adianthifolia. Bioorg Med Chem 12: 4725-4734, 2004.

10. Raju J, Patlolla JM, Swamy MV and Rao CV: Diosgenin, a steroid saponin of Trigonella foenum graecum (Fenugreek), inhibits azoxymethane-induced aberrant crypt foci formation in F344 rats and induces apoptosis in HT-29 human colon cancer cells. Cancer Epidemiol Biomarkers Prev 13: 1392-1398, 2004.

11. Thompson CB: Apoptosis in the pathogenesis and treatment of disease. Science 267: 1456-1462, 1995.

12. Perlman H, Pagliari LJ and Volin MV: Regulation of apoptosis and cell cycle activity in rheumatoid arthritis. Curr Mol Med 1: 597-608, 2001.

13. Firestein GS: Evolving concepts of rheumatoid arthritis. Nature 423: 356-361, 2003.

14. Nishioka K, Hasunuma T, Kato T, Sumida T and Kobata T: Apoptosis in rheumatoid arthritis: a novel pathway in the regulation of synovial tissue. Arthritis Rheum 41: 1-9, 1998.

15. Baier A, Meineckel I, Gay S and Pap T: Apoptosis in rheumatoid arthritis. Curr Opin Rheumatol 15: 274-279, 2003.

16. Liagre B, Vergne-Salle P, Corbiere C, Charissoux JL and Beneytout JL: Diosgenin, a plant steroid, induces apoptosis in human rheumatoid arthritis synoviocytes with cyclooxygenase-2 overexpression. Arthritis Res Ther 6: R373-R383, 2004.

17. Corbiere C, Liagre B, Bianchi A, Bordji K, Dauca M, Netter P and Beneytout JL: Different contribution of apoptosis to the antiproliferative effects of diosgenin and other plant steroids, hecogenin and tigogenin, on human 1547 osteosarcoma cells. Int J Oncol 22: 899-905, 2003.

18. Trouillas P, Corbiere C, Liagre B, Duroux JL and Beneytout JL: Structure-function relationship for saponin effects on cell cycle arrest and apoptosis in the human 1547 osteosarcoma cells: a molecular modelling approach of natural molecules structurally close to diosgenin. Bioorg Med Chem 13: 1141-1149, 2005.
19. Arnett FC, Edworthy SM, Bloch DA, et al: The American Rheumatism Association 1987 revised criteria for the classification of rheumatoid arthritis. Arthritis Rheum 31: 315-324, 1988.

20. Liagre B, Vergne P, Rigaud M and Beneytout JL: Expression of arachidonate platelet-type 12-lipoxygenase in human rheumatoid arthritis type B synoviocytes. FEBS Lett 414: 159-164, 1997.

21. Moalic S, Liagre B, Labrousse F and Beneytout JL: Enhanced apoptosis in retrovirally transfected osteosarcoma cells after exposure to sodium butyrate. Int J Oncol 16: 695-700, 2000.

22. Liagre B, Bertrand J, Leger DY and Beneytout JL: Diosgenin, a plant steroid, induces apoptosis in COX-2 deficient K562 cells with activation of the p38 MAP kinase signalling and inhibition of NF- $\kappa \mathrm{B}$ binding. Int J Mol Med 16: 1095-1101, 2005.

23. Leger DY, Liagre B and Beneytout JL: Low dose leflunomide activates PI3K/Akt signalling in erythroleukemia cells and reduces apoptosis induced by anticancer agents. Apoptosis 11: 1747-1760, 2006.

24. Leger DY, Liagre B, Corbiere C, Cook-Moreau J and Beneytout JL: Diosgenin induces cell cycle arrest and apoptosis in HEL cells with increase in intracellular calcium level, activation of cPLA2 and COX-2 overexpression. Int J Oncol 25: 555-562, 2004.

25. Matsuda H, Pongpiriyadacha Y, Morikawa T, Kishi A, Kataoka S and Yoshikawa M: Protective effects of steroid saponins from Paris polyphylla var. yunnanensis on ethanol- or indomethacininduced gastric mucosal lesions in rats: structural requirement for activity and mode of action. Bioorg Med Chem Lett 13: 1101-1106, 2003.

26. Myszka H, Bednarczyk D, Najder M and Kaca W: Synthesis and induction of apoptosis in $\mathrm{B}$ cell chronic leukemia by diosgenyl 2-amino-2-deoxy-beta-D-glucopyranoside hydrochloride and its derivatives. Carbohydr Res 338: 133-141, 2003.

27. Wang Z, Zhou J, Ju Y, Zhang H, Liu M and Li X: Effects of two saponins extracted from the polygonatum Zanlanscianense pamp on the human leukemia (HL-60) cells. Biol Pharm Bull 24: 159-162, 2001.

28. Liagre B, Leger DY, Vergne-Salle P and Beneytout JL: MAP kinase subtypes and Akt regulate diosgenin-induced apoptosis of rheumatoid synovial cells in association with COX-2 expression and prostanoid production. Int J Mol Med 19: 113-122, 2007.

29. Hibasami H, Moteki H, Ishikawa K, et al: Protodioscin isolated from fenugreek (Trigonella foenumgraecum L.) induces cell death and morphological change indicative of apoptosis in leukemic cell line $\mathrm{H}-60$, but not in gastric cancer cell line KATO III. Int J Mol Med 11: 23-26, 2003.

30. Vaishnaw AK, McNally JD and Elkon KB: Apoptosis in the rheumatic diseases. Arthritis Rheum 40: 1917-1927, 1997.

31. Thornberry NA and Lazebnik Y: Caspases: enemies within. Science 281: 1312-1316, 1998.

32. Callsen D and Brune B: Role of mitogen-activated protein kinases in S-nitrosoglutathione-induced macrophage apoptosis. Biochemistry 38: 2279-2286, 1999.

33. Xia Z, Dickens M, Raingeaud J, Davis RJ and Greenberg ME: Opposing effects of ERK and JNK-p38 MAP kinases on apoptosis. Science 270: 1326-1331, 1995.

34. Johnson GL and Lapadat R: Mitogen-activated protein kinase pathways mediated by ERK, JNK, and p38 protein kinases. Science 298: 1911-1912, 2002.

35. Neff L, Zeisel M, Druet V, Takeda K, Klein JP, Sibilia J and Wachsmann D: ERK 1/2- and JNKs-dependent synthesis of interleukins 6 and 8 by fibroblast-like synoviocytes stimulated with protein I/II, a modulin from oral streptococci, requires focal adhesion kinase. J Biol Chem 278: 27721-27728, 2003.

36. Vergne-Salle P, Leger DY, Bertin P, Treves R, Beneytout JL and Liagre B: Effects of the active metabolite of leflunomide, A77 1726, on cytokine release and the MAPK signalling pathway in human rheumatoid arthritis synoviocytes. Cytokine 31: 335-348, 2005.

37. Han Z, Boyle DL, Chang L, et al: c-Jun N-terminal kinase is required for metalloproteinase expression and joint destruction in inflammatory arthritis. J Clin Invest 108: 73-81, 2001.

38. Schett G, Tohidast-Akrad M, Smolen JS, et al: Activation, differential localization, and regulation of the stress-activated protein kinases, extracellular signal-regulated kinase, c-JUN Nterminal kinase, and p38 mitogen-activated protein kinase, in synovial tissue and cells in rheumatoid arthritis. Arthritis Rheum 43: 2501-2512, 2000. 
39. Hammaker D, Sweeney S and Firestein GS: Signal transduction networks in rheumatoid arthritis. Ann Rheum Dis 62: 86-89, 2003.

40. Morel J and Berenbaum F: Signal transduction pathways: new targets for treating rheumatoid arthritis. Joint Bone Spine 71: 503-510, 2004.

41. Yen ML, Su JL, Chien CL, et al: Diosgenin induces hypoxiainducible factor-1 activation and angiogenesis through estrogen receptor-related phosphatidylinositol 3-kinase/Akt and p38 mitogen-activated protein kinase pathways in osteoblasts. Mol Pharmacol 68: 1061-1073, 2005.

42. Vergne P, Liagre B, Bertin P, Cook-Moreau J, Treves R, Beneytout JL and Rigaud M: Methotrexate and cyclooxygenase metabolism in cultured human rheumatoid synoviocytes. J Rheumatol 25: 433-440, 1998

43. Liagre B, Vergne P, Rigaud M and Beneytout JL: Arachidonate 15-lipoxygenase of reticulocyte-type in human rheumatoid arthritis type B synoviocytes and modulation of its activity by proinflammatory cytokines. J Rheumatol 26: 1044-1051, 1999.

44. Martel-Pelletier J, Pelletier JP and Fahmi H: New insights into prostaglandin biology. J Rheumatol 31: 14-16, 2004.

45. Prescott SM: Is cyclooxygenase- 2 the alpha and the omega in cancer? J Clin Invest 105: 1511-1513, 2000.
46. Steinbach G, Lynch PM, Phillips RK, et al: The effect of celecoxib, a cyclooxygenase- 2 inhibitor, in familial adenomatous polyposis. N Engl J Med 342: 1946-1952, 2000.

47. Xu Z, Choudhary S, Voznesensky O, et al: Overexpression of COX-2 in human osteosarcoma cells decreases proliferation and increases apoptosis. Cancer Res 66: 6657-6664, 2006.

48. Kemick ML, Chin JE and Wuthier RE: Role of prostaglandins in differentiation of growth plate chondrocytes. Adv Prostaglandin Thromboxane Leukot Res 19: 423-426, 1989.

49. Pelletier JP, Fernandes JC, Jovanovic DV, Reboul P and Martel-Pelletier J: Chondrocyte death in experimental osteoarthritis is mediated by MEK $1 / 2$ and $\mathrm{p} 38$ pathways: role of cyclooxygenase-2 and inducible nitric oxide synthase. J Rheumatol 28: 2509-2519, 2001.

50. Jovanovic DV, Mineau F, Notoya K, Reboul P, Martel-Pelletier J and Pelletier JP: Nitric oxide induced cell death in human osteoarthritic synoviocytes is mediated by tyrosine kinase activation and hydrogen peroxide and/or superoxide formation. J Rheumatol 29: 2165-2175, 2002.

51. Moalic S, Liagre B, Corbiere C, Bianchi A, Dauca M, Bordji K and Beneytout JL: A plant steroid, diosgenin, induces apoptosis, cell cycle arrest and COX activity in osteosarcoma cells. FEBS Lett 506: 225-230, 2001. 